\title{
ANALYSIS OF THE CELL MEMBRANE FATTY ACIDS AND CHARACTERIZATION OF THE PSYCHROTOLERANT SERRATIA MARCESCENS HIG ISOLATED FROM HOPAR (BUALTAR) GLACIER, PAKISTAN
}

\author{
HASSAN, N. ${ }^{1}$ - UdDIN, S. ${ }^{1}$ - RAFIQ, M..$^{1,2}$ - UR REHMAN, H. ${ }^{1}$ - HALEEM, A. ${ }^{1}$ - HAYAT, M. ${ }^{1}$ - \\ KHAN, M. ${ }^{1}-$ JAMIL, S. U. U. ${ }^{1,3}-$ HASAN, F. ${ }^{1 *}$ \\ ${ }^{1}$ Applied, Environmental and Geomicrobiology Laboratory, Department of Microbiology \\ Quaid-i-Azam University, Islamabad 45320, Pakistan \\ ${ }^{2}$ Bristol Glaciology Centre, School of Geographical Sciences, Faculty of Science \\ University of Bristol, Bristol, BS8 1SS, United Kingdom \\ ${ }^{3}$ Department of Earth and Environmental Sciences, Bahria University, Islamabad, Pakistan \\ *Corresponding author \\ e-mail:farihahasan@yahoo.com; phone: +92-51-9064-3065 \\ (Received 23 ${ }^{\text {rd }}$ Apr 2019; accepted $2^{\text {nd }}$ Jul 2019)
}

\begin{abstract}
In this study, the bacterial isolate HI6 was recovered from the ice of the Hopar (Bualtar) glacier, Karakoram Mountain Range, Pakistan. Isolate HI6 was identified as Serratia marcescens through microscopic and molecular analysis (16S rRNA sequencing). Serratia marcescens HI6 was analyzed for different physiological characteristics including temperature, $\mathrm{pH}$ and culture media. Serratia marcescens HI6 showed best growth at $25^{\circ} \mathrm{C}$, on LB medium and $\mathrm{pH}$ 7. In addition, the Fatty acid methyl ester (FAME) was extracted and subjected to Fourier Transform infrared (FTIR) and Gas chromatography/mass spectroscopy (GC/MS) analysis. FTIR and GC/MS analysis has revealed that cell membrane of Serratia marcescens HI6 contains various types of fatty acids (FA). $i-$ C16:1 (35.3\% out of total cell membrane fatty acids) was found most predominantly followed by $i-\mathrm{C} 15: 1(18.5 \%)$ and $n$-C16 (13.2\%). Moreover, branched fatty acids $(62 \%)$ including monounsaturated fatty acids (MUFA) (e.g. $i-$ C15:1 and $i-\mathrm{C} 16: 1)$ and saturated fatty acids (SFA) were the dominant types of fatty acids in the cell membrane. A polyunsaturated fatty acid (PUFA), C18:2(cis-9) (known as linoleic acid) was also detected among analyzed fatty acids.
\end{abstract}

Keywords: 16S rRNA, Fatty acid methyl ester, Fourier Transform infrared, Gas chromatography / mass spectroscopy

\section{Introduction}

Genus Serratia belonging to family Enterobacteriaceae and species of genus Serratia share very close genotypic and phenotypic characteristics with each other (Grimont and Grimont, 2006; Karkey et al., 2018). A bacterium with ability to produce red pigments was first observed on polenta by Bizio (1823), which was later identified and named as Serratia marcescens (Martinec and Kocur, 1961a). Williams and Qadri (1980) have observed many strains of Serratia marcescens that were producing a non-diffusible red pigment prodigiosin. The prodigiosin (red colour pigment) produced by these strains appeared akin to a blood stain with quite devastating consequences on various human consumable items such as consecrated wafers, bread, and polenta (Grimont and Grimont, 2006). In this perspective, many researchers had linked the genus Serratia's history, hundreds of years back (Harrison, 1924; Gaughran, 1969; Reid, 1982). Although, prodigiosin or prodigiosinlike pigments or various types of pigments with red colour, have also been observed 
produced by some bacterial species other than Serratia (Williams and Qadri, 1980), thus characteristics of microbes concerning these prominent phenomena can only be deduced.

Serratia marcescens, an Enterobacteriaceae family member, is a Gram-negative rod that inhabits soil and water (Szewzyk et al., 1993; Sandner-Miranda et al., 2018; Yeung et al., 2018). It is a saprophytic bacterium, and has been identified in food, notably in starchy variants which offer a marvelous growth environment. Previously it was known as Chromobacterium prodigiosum (Wheat et al., 1951; Sleigh, 1983; Ghaith et al., 2018), Bizio proposed the name Serratia marcescens in 1823, which was later used by Gaughran, in 1969. Some environmental isolates were reported to produce characteristic red pigment prodigiosin, and formerly it was confused with fresh blood (Gaughran, 1969). It is an omnipresent bacterium and widely found in natural habitats such as soil, honeybee gut, water, air, plants and animals (Grimont and Grimont, 1984; Raymann et al., 2017; DharPurkayastha et al., 2018; Yeung et al., 2018). The biosynthesis of prodigiosin is an important attribute of Serratia marcescens (Grimont and Grimont, 1984). Over past few years, it has been known as main causative agent of hospital acquired infections (Mahlen, 2011; Montagnani et al., 2015).

Membrane lipid homeostasis has been shown to play a significant role in bacterial physiology. Escherichia coli was used as a study model bacterium for research in lipid biosynthesis for ages (Parsons and Rock, 2013). Biosynthesis of unsaturated fatty acids is a key factor in bacterial membrane homeostasis (Zhang and Rock, 2008). Combination of fatty acids with different melting points was integrated into phospholipids. Bacteria cope with low temperature by increasing the degree of unsaturation of fatty acids incorporated in phospholipids, which leads to high membrane fluidity (Parsons and Rock, 2013). In addition, in order to maintain membrane fluidity at lower temperatures, bacteria integrate fatty acids with lower melting points into lipid bilayer with decrease of outer temperatures that help bacteria to keep balance the order-disorder transition of temperature of the membranes (Suutari and Laakso, 1994; Annous et al., 1997; Bajerski et al., 2017). It is evident from previous studies that high temperature leads to high membrane rigidity, which can be handle by decrease in degree of unsaturation of fatty acids (Ganzert et al., 2011; Bakermans et al., 2012; Bajerski and Wagner, 2013).

A variety of mechanisms are used by bacteria to sustain membrane integrity to cope with temperature changes (Parsons and Rock, 2013). In previous studies, Serratia marcescens has been well documented for occurrence of fatty acids in its general cell structure but not specifically in the cell membrane (Bishop and Still, 1963; Bergan et al., 1983). Bermingham et al. (1971) has reported stimulation of growth and production of pigments at temperatures higher than normal by long-chain unsaturated fatty acids in Serratia marcescens. The current research work was aimed to study and characterize cell membrane fatty acid profile of psychrotolerant bacterial isolate from Hopar glacier also known as Bualtar glacier in Pakistan.

\section{Materials and Methods}

\section{Selection of the isolate HI6}

Isolate HI6 (Hopar ice) (selected for this study) was previously isolated from glacial ice, Hopar glacier $\left(36^{\circ} 12^{\prime} 54.77 \mathrm{~N}, 7^{\circ} 46^{\prime} 9.49\right.$ E) using Luria Bertani (LB) agar (Table 1) and incubated at $15^{\circ} \mathrm{C}$. After initial isolation, the isolate HI6 was preserved in $30 \%$ glycerol using Luria Bertani broth (LB) (Table 1) as culture medium and stored at $-20^{\circ} \mathrm{C}$ for future use. 


\section{Morphology of the isolate HI6}

The colony morphology of the isolate HI6 was observed and recorded in terms of shape, production of pigments, size, opacity, margin, elevation and texture. Gram staining of the isolate HI6 was done following the protocol described by Beveridge (2001) and microscopic features were recorded using Laxco ${ }^{\mathrm{TM}}$ LMC-3000 Series Bright field Compound Microscope System.

Table 1. The composition of the applied culture mediums in detail

\begin{tabular}{c|c}
\hline \multicolumn{2}{c}{ Composition of Luria Bertani $\left(\mathrm{g} \mathrm{l}^{\mathbf{- 1}}\right)$} \\
\hline Luria Bertani Agar $(\boldsymbol{L B A})$ & 10 \\
Tryptone & 5 \\
Sodium chloride & 5 \\
Yeast extract & 15 \\
Agar & 10 \\
\hline Luria Bertani Broth $(\boldsymbol{L B B})$ & 5 \\
Tryptone & 5 \\
\hline Sodium chloride & \\
Yeast extract &
\end{tabular}

\section{Molecular identification of the isolate HI6}

\section{DNA extraction, PCR amplification}

The DNA of the isolate HI6 was extracted using the protocol described by Zhou et al. (1996). The extracted DNA was amplified using the thermocycler (T100 ${ }^{\mathrm{TM}}$ Thermal cycler, Bio-Rad Laboratories, Inc.). The universal bacterial primers 27F (5'-AGAGTTTGATCMTGGCTCAG3-') and 1492R (5'-GGTTACCTTGTTACGACTT-3') were used for amplification purposes. Cycling conditions was used as initial denaturation at $94^{\circ} \mathrm{C}$ for $1 \mathrm{~min}$ following by 30 cycles at $94^{\circ} \mathrm{C}$ for $1 \mathrm{~min}, 55^{\circ} \mathrm{C}$ for $1 \mathrm{~min}$ and $72^{\circ} \mathrm{C}$ followed by final elongation at $72^{\circ} \mathrm{C}$ for $7 \mathrm{~min}$. Finally, $2 \%$ agarose gel electrophoresis was performed to confirm PCR amplification.

\section{Sequencing and phylogenetic analysis}

Sequencing (16S rRNA) of amplified PCR product of the isolate HI6 was done by Macrogen Inc. Seoul, Korea. Trimming and filtering of obtained sequences was done using BioEdit (v7.0.5). The trimmed sequences was used to find the homologous bacterial strain by searching in the National Centre for Biotechnology Information (NCBI) (Thompson et al., 1994). Tamura-Nei model (Tamura and Nei, 1993) was used to construct the evolutionary history of the isolate HI6. MEGA 6.0 software was used to construct phylogenetic tree at the bootstrap value of 1000 .

\section{Characterization of physiological parameters of the isolate HI6}

Effect of different $\mathrm{pH}$, media and temperature on growth of the isolate HI6 was evaluated in this study. Four different temperature, 5, 15, 25 and $35^{\circ} \mathrm{C}$, five different media, Minimal salt medium (MSM), Luria Bertani (LB), Nutrient broth (NB), Peptone-yeast-meat extracts (PYM) and Artificial salt media (ASM) as well as five different $\mathrm{pH}, 3,5,7,9$ and 11 were selected for this experiment. Nutrient broth was used as culture medium for all temperature and $\mathrm{pH}$ experiments, whereas, $15^{\circ} \mathrm{C}$ as incubation temperature was used for $\mathrm{pH}$ research work. 7 days old culture of the isolate 
HI6 was inoculated in $250 \mathrm{~mL}$ Erlenmeyer flask containing $100 \mathrm{~mL}$ of broth medium and incubated in shaking incubator with $120 \mathrm{rpm}$ for 7 days. To check the growth, optical density $(600 \mathrm{~nm})$ of the isolate HI6 was recorded after every $24 \mathrm{hrs}$ via spectrophotometer (Shimadzu). In addition, two-way ANOVA was applied to find the statistical significant of this experiment.

\section{Cell membrane fatty acids analysis}

Fatty acids methyl ester preparation (FAME)

The isolate HI6 was grown in LB broth and incubated at $15^{\circ} \mathrm{C}$ for seven days. About $100 \mathrm{mg}$ culture of the isolate HI6 was taken in $20 \mathrm{~mL}$ glass vial and subjected to FAME extraction. Added $2 \mathrm{~mL}$ of $5 \%$ methanolic $\mathrm{HCl}$ to glass vial containing bacterial culture and heated at $70^{\circ} \mathrm{C}$ for 2 hours. After heating, glass vial was placed at room temperature for 30 minutes to cool down. In next step, distilled water $(1 \mathrm{~mL})$ was added and then vortexed well. For extraction of FAME, $1 \mathrm{~mL}$ of hexane was poured and vigorously vortexed for about 10 minutes. After formation of two layers in glass tube, upper layer was transferred to new $2 \mathrm{~mL}$ clean glass vail and stored under nitrogen at $-20^{\circ} \mathrm{C}$.

\section{Fourier Transform infrared (FTIR) spectroscopy}

The extracted FAME extracted from the isolate HI6 was analysed through by FTIR spectrophotometer (Bruker Tensor 27, equipped with ZnSe ATR) along with the standard obtained through (The Vitamin Company USA). The spectra of FAME from the isolate HI6 were evaluated and recorded by keeping the range in between $4000-600 \mathrm{~cm}^{-1}$. About $35 \mu \mathrm{L}$ (in triplicate) of extracted FAME was placed on the FTIR spectrophotometer tray and recorded infrared spectrum of sample. The software Opus 65 was used to compare spectrum of extracted FAME with the spectrum of known compounds present in library.

\section{Gas chromatography/mass spectroscopy (GC/MS) analysis}

FAMEs analysis was done via GC (Agilent 7890A GC) linked to MS (Agilent 5975C MSD) and controlled by a HP Compaq computer using ChemStation software by following protocol described by Abd El Razak et al. (2014). Helium used as a carrier gas (flow rate of $1 \mathrm{ml} / \mathrm{min}$, initial pressure of $50 \mathrm{kPa}$, split at $10 \mathrm{ml} / \mathrm{min}$ ). Moreover, an auto-sampler (HP7683B) was used for injecting about $1 \mu \mathrm{L}$ of sample in hexane. In addition, FAMEs separation was carried with column $(30 \mathrm{~m} \times 0.25 \mathrm{~mm})$ (An Agilentfused silica capillary column) coated with $0.25 \mu \mathrm{m}$ dimethyl poly-siloxane (HP-5). The temperature of $\mathrm{GC}$ was set initially from 30 to $130^{\circ} \mathrm{C}$ at $5^{\circ} \mathrm{C} / \mathrm{min}$ then to $300^{\circ} \mathrm{C}$ at $20^{\circ} \mathrm{C} / \mathrm{min}$ and final temperature held for $5 \mathrm{~min}$. FAME Mix (C4-C24) (Sigma-Aldrich) was used to identify the resultant peaks by comparing mass spectra and $\mathrm{R}_{\mathrm{t}}$ (retention time).

\section{Results \\ Morphology and molecular identification}

The isolate HI6 produced red pigment, with round, smooth, convex (3-6 $\mathrm{mm}$ in diameter) colonies (Fig. 1). Microscopic analysis showed the isolate HI6 as Gram negative short rod $(0.7-2.3 \mu \mathrm{m}$ in length and $0.3-0.8 \mu \mathrm{m}$ in diameter). 


$$
-11915 \text { - }
$$

Based on 16S rRNA sequencing, the bacterial isolate HI6 was identified as Serratia marcescens [GenBank accession number MG641443]. In addition, the isolate HI6 showed $100 \%$ similarity with Serratia marcescens after searching in National Centre for Biotechnology Information database. Phylogenetic analysis on basis of partial 16S gene sequence, clearly shows that Serratia marcescens HI6 grouped within clusters of closely related species of Serratia marcescens in phylogenetic tree (Fig. 2).
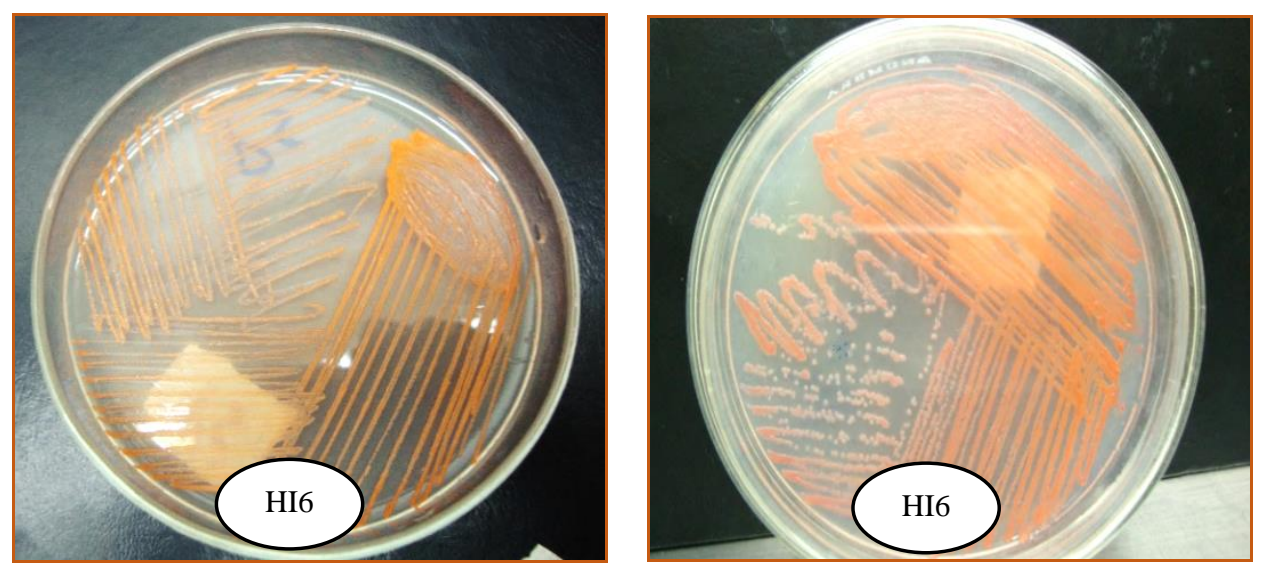

Figure 1. The colony morphology of the isolate HI6 with production of red pigment

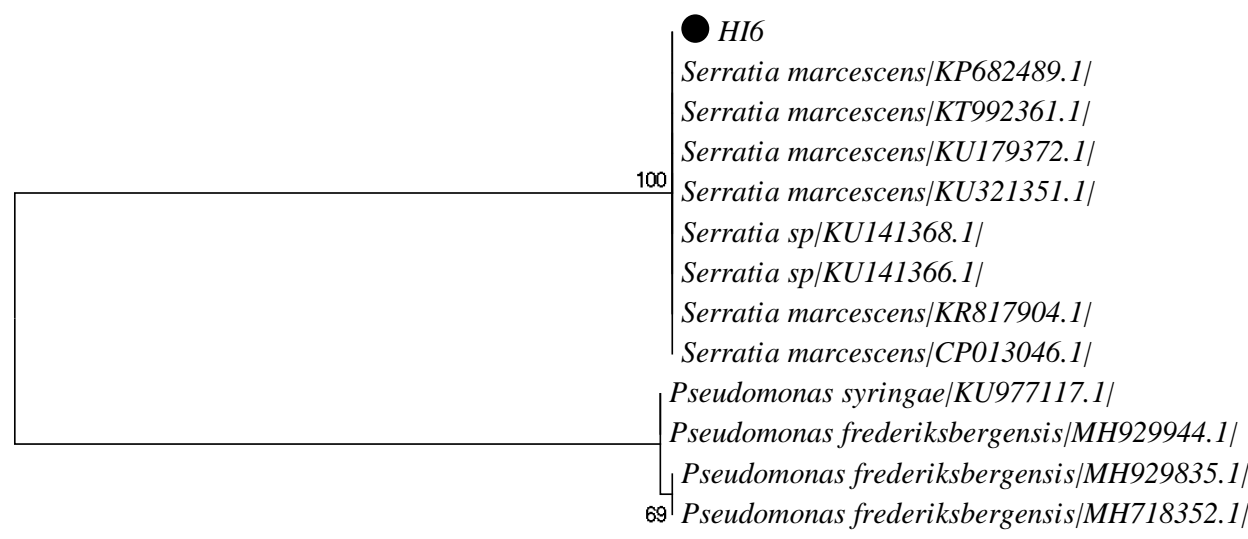

0.02

Figure 2. Analysis of evolutionary relationship and relatedness of Serratia marcescens HI6 based on partial $16 S$ gene sequences with closely related species by Maximum Likelihood method. Bootstrap values (1000 replicates) for node values from $50 \%$ are indicated. The species belonging to genus Pseudomonas were used as an outgroup

\section{Physiological characteristics}

Serratia marcescens HI6 responded differently to various physiological parameters. In this experiment, it has been found that Serratia marcescens HI6 grow optimally at $25^{\circ} \mathrm{C}$ and $\mathrm{pH} 7$ in LB broth (Table 2). The Serratia marcescens HI6 showed decline in its growth after $120 \mathrm{hrs}$ of initial incubation in about all physiological parameters. It seemed that it has entered in exponential growth phase after $48 \mathrm{hrs}$ of its starting incubation. Serratia marcescens HI6 was unable to show any growth at $\mathrm{pH} 3$ and $45^{\circ} \mathrm{C}$. 
The LB broth was reported as best growth medium followed by PYM, ASW, MSM and NA. In addition, optimum growth was at $\mathrm{pH} 7$ followed by $\mathrm{pH}$ 9, 11 and 5. Moreover, best growth was observed at $25^{\circ} \mathrm{C}$ followed by 35,15 and $5^{\circ} \mathrm{C}$. Based on these results, Serratia marcescens HI6 had the capabilities to grow at wide range of extreme physiological parameters.

Table 2. Growth characteristics of the Serratia marcescens HI6 on different physiological parameters

\begin{tabular}{|c|c|c|c|c|c|c|c|c|c|}
\hline \multirow{2}{*}{ Isolate } & \multicolumn{9}{|c|}{ Physiological parameters } \\
\hline & \multicolumn{3}{|l|}{ Temp $\left({ }^{\circ} \mathrm{C}\right)$} & \multicolumn{4}{|c|}{ Time of incubation in hrs and OD' } & \multirow[b]{2}{*}{144} & \multirow[b]{2}{*}{168} \\
\hline \multirow{20}{*}{ HI6 } & & $\mathbf{0}$ & 24 & 48 & 72 & 96 & 120 & & \\
\hline & 5 & 0.243 & 0.578 & 0.710 & 0.989 & 1.219 & 1.487 & 1.398 & 1.387 \\
\hline & 15 & 0.123 & 0.256 & 0.794 & 1.091 & 1.883 & 1.980 & 2.106 & 1.970 \\
\hline & 25 & 0.473 & 0.869 & 1.420 & 1.756 & 1.999 & 2.209 & 2.439 & 2.429 \\
\hline & 35 & 0.490 & 0.898 & 1.321 & 1.580 & 1.784 & 1.985 & 2.001 & 1.973 \\
\hline & 45 & 0.123 & 0.077 & - & - & - & - & - & - \\
\hline & pH & \multicolumn{8}{|c|}{ Time of incubation in hrs and OD } \\
\hline & & $\mathbf{0}$ & 24 & 48 & 72 & 96 & 120 & 144 & 168 \\
\hline & 3 & 0.143 & 0.131 & - & - & - & - & - & - \\
\hline & 5 & 0.113 & 0.148 & 0.213 & 0.199 & 0.0722 & 0.063 & 0.060 & 0.058 \\
\hline & 7 & 0.123 & 0.256 & 0.794 & 1.091 & 1.883 & 1.980 & 2.106 & 1.970 \\
\hline & 9 & 0.134 & 0.230 & 0.753 & 0.963 & 1.352 & 1.103 & 1.102 & 1.090 \\
\hline & 11 & 0.135 & 0.174 & 0.213 & 0.219 & 0.190 & 0.179 & 0.169 & 0.157 \\
\hline & Media & \multicolumn{8}{|c|}{ Time of incubation in hrs and OD } \\
\hline & & $\mathbf{0}$ & 24 & 48 & 72 & 96 & 120 & 144 & 168 \\
\hline & ASW & 0.020 & 0.0311 & 1.092 & 1.568 & 1.578 & 1.597 & 1.558 & 1.497 \\
\hline & LB & 0.123 & 0.256 & 0.794 & 1.091 & 1.883 & 1.980 & 2.106 & 1.970 \\
\hline & MSM & 0.041 & 0.052 & 0.059 & 0.890 & 1.480 & 1.501 & 1.450 & 1.399 \\
\hline & NA & 0.023 & 0.032 & 0.052 & 1.129 & 1.068 & 1.204 & 1.189 & 1.179 \\
\hline & PYM & 0.146 & 0.246 & 0.240 & 0.994 & 1.758 & 1.854 & 1.869 & 1.778 \\
\hline
\end{tabular}

Keys: ${ }^{1}$ Optical density, ${ }^{*} p$ value for the $\mathrm{pH}$ and media experiment was $>0.05,{ }^{*} p$ value for the temperature experiment was $<0.05$

\section{Fourier Transform infrared (FTIR) analysis}

Results of FTIR analysis revealed different functional groups present in the FAME extracted from Serratia marcescens HI6 (Fig. 3). The spectrum of the analysed FAME was compared with already online available databases as well as with standard and found that typical functional groups that are exist in fatty acids (FA) (such as saturated FA, monounsaturated FA and polyunsaturated FA), have also been presented in analysed FAME. For example, peak value 2812-3012 $\mathrm{cm}^{-1}$ region (which represent $=\mathrm{C}-\mathrm{H}$ stretching vibration bond), $1710-1766 \mathrm{~cm}^{-1}$ (associated with $\mathrm{C}=\mathrm{O}$ carbonyl bond) and multiple $\mathrm{C}=\mathrm{C}$ double bond at $1400-1600 \mathrm{~cm}^{-1}$, have clearly indicated that Serratia marcescens HI6 had various types of saturated FA, monounsaturated FA and polyunsaturated FA in its cell membrane (Fig. 3).

\section{Gas chromatography/mass spectroscopy (GC/MS) analysis}

The results of GC/MS has revealed that most copious types of fatty acids were branched fatty acids followed by monounsaturated fatty acids, n-chain saturated fatty acids, hydroxyl fatty acids and polyunsaturated fatty acids (Fig. 4a,b) (Table 3). In addition, $i-\mathrm{C} 16: 1$ was found most abundant type of fatty acid followed by $i-\mathrm{C} 15: 1$, $\mathrm{n}-\mathrm{C} 18: 2($ cis-9), $\mathrm{n}-\mathrm{C} 16, a i-\mathrm{C} 17: 0,3-\mathrm{OH}-\mathrm{C} 14: 0, \mathrm{n}-\mathrm{C} 12, \mathrm{n}-\mathrm{C} 14, i-\mathrm{C} 17: 0, \mathrm{n}-\mathrm{C} 18$, n-C18:1(trans-9), C18:2(cis-9), n-C15 and n-C17 (Table 3). 


$$
-11917 \text { - }
$$

Moreover, Serratia marcescens HI6 was able to produce only one type of polyunsaturated fatty acids, n-C18:2(cis-9) (also known as linoleic acid). Overall, branched fatty acids (62\%) and $i-\mathrm{C} 16: 1$ (35.2\% out of total membrane fatty acids) were the main types of fatty acids produced by Serratia marcescens HI6 predominantly.

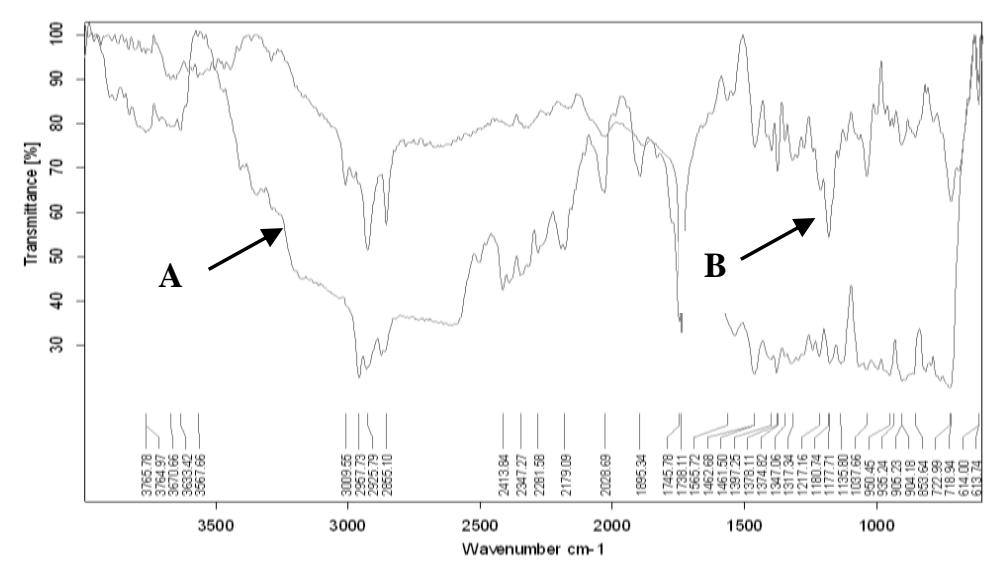

Figure 3. Fourier Transform infrared (FTIR) spectrum of FAME extracted from the Serratia marcescens HIG. (A) Extracted FAME of the Serratia marcescens HIG(B) Standard

\section{FA distribution}

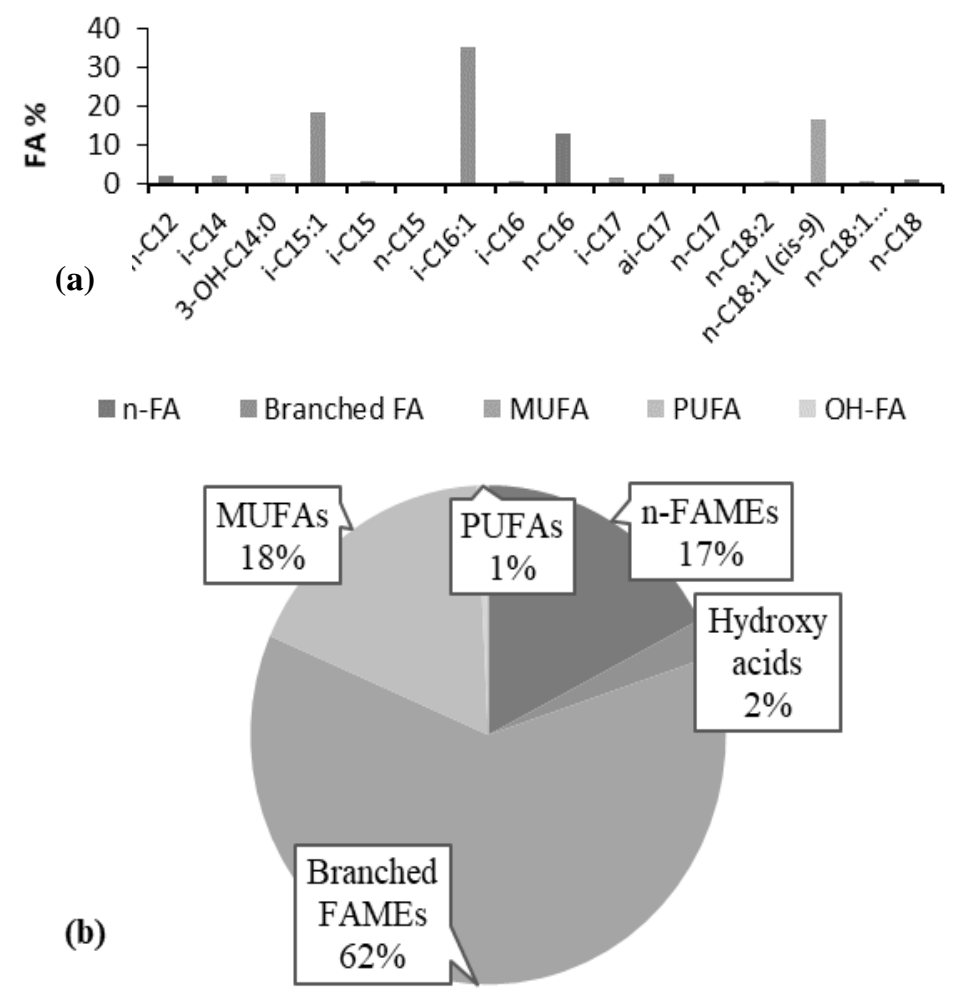

Figure 4a,b. (a) Distribution of individual fatty acids in the cell membrane of Serratia marcescens HI6 (b) Percentage of the main types of fatty acids in the cell membrane of Serratia marcescens HIO 
Table 3. Distribution and percentage of fatty acids in the cell membrane of the Serratia marcescens HI6

\begin{tabular}{c|c|c|c|c}
\hline Isolate & $\begin{array}{c}\text { Carbon Chain } \\
\text { length }\end{array}$ & Retention time & IUPIC names & $\begin{array}{c}\text { \%/total CM fatty } \\
\text { acids }\end{array}$ \\
\hline & $n-\mathrm{C} 12$ & 16.34 & Dodecanoate & 2.1 \\
& $i-\mathrm{C} 14: 0$ & 20.72 & (Z)-tetradec-9-enoate & 2.0 \\
& $3-\mathrm{OH}-\mathrm{C} 14: 0$ & 25.18 & 3-Hydroxytetradecanoate & 2.46 \\
& $i-\mathrm{C} 15: 1$ & 20.46 & iso-10-Pentadecenoate & 18.5 \\
& $i-\mathrm{C} 15: 0$ & 23.20 & iso-Pentadecanoate & 0.6 \\
& $n-\mathrm{C} 15$ & 24.08 & Pentadecanoate & 0.5 \\
Serratia & $i-\mathrm{C} 16: 1$ & 24.89 & (Z)-hexadec-9-enoate & 35.2 \\
marcescens & $i-\mathrm{C} 16: 0$ & 25.67 & iso-Hexadecanoate & 1.0 \\
HI6 & $n-\mathrm{C} 16$ & 26.57 & Hexadecanoate & 13.2 \\
& $i-\mathrm{C} 17: 0$ & 27.28 & iso-Heptadecanoate & 1.6 \\
& $a i-\mathrm{C} 17: 0$ & 28.05 & anteiso-Heptadecanoate & 2.7 \\
& $n-\mathrm{C} 17$ & 28.85 & Heptadecanoate & 0.5 \\
& $\mathrm{C} 18: 2($ cis-9) & 30.43 & (9Z,12Z)-octadeca-9,12-dienoate & 0.76 \\
& $\mathrm{C} 18: 1$ (cis-9) & 30.45 & (Z)-octadec-9-enoate & 16.8 \\
& $\mathrm{C} 18: 1$ trans-9) & 30.59 & (E)-octadec-9-enoate & 1.0 \\
& $n-\mathrm{C} 18$ & 31.15 & Octadecanoate & 1.1 \\
\hline
\end{tabular}

Keys: $i=$ iso, $a i=$ anteiso, $\mathrm{CM}=$ cell membrane, IUPIC $=$ International Union of Pure and Applied Chemistry

\section{Discussion}

This study was aimed to characterize physiological parameters and analyzed cell membrane fatty acids of the bacterium isolate Serratia marcescens HI6. In our knowledge, we are reporting for the first time Serratia marcescens from any glacial environment of Pakistan. Although in one study, it has been studied for laccase production isolated from glacial site in Indian Himalayan Region (IHR) (Kaira et al., 2015). Serratia marcescens has been known for its abilities to infect insects and spoils various types of food (Flyg and Xanthopoulos, 1983; Abdour, 2003; Bahar and Demirbag, 2007). In addition, its association with promotion of plant growth by combating with plant pathogens has also been observed (Kloepper et al., 1993). Moreover, Serratia marcescens has been found to fertile soils by producing phosphatases and unfriendly substances for plant pathogens (de Queiroz and de Melo, 2006; Tripura et al., 2007). Likewise, Pares (1964) has observed in soil that Serratia marcescens had role in the nutrient recycling by solubilizing organic iron and dissolving gold and copper. In another research, Janota-Bassalik (1963) has reported mineralization role of psychrotolerant Serratia marcescens accompanying by low-moor peat.

The genus Serratia is usually found widely in water, plants, mammals and hospitalized human patients (Grimont and Grimont, 2006) but studies about its presence and activities in both Polar and Non-polar cold regions are very rare. The primary habitat for genus Serratia is water as plenty of species belonged to Serratia has been reported from water (Grimont and Grimont, 2006). Gavini et al. (1979) has isolated Serratia fonticola well waters and springs. In another study conducted by Grimont and Grimont (2006), a total of 150 bacterial species belonged to genus Serratia including Serratia marcescens were reported from river water. In addition, Groscop and Brent (1964) has observed toxicity of non-diffusible red pigment prodigiosin to protozoa, produced by genus Serratia, which perhaps a promising factor important for its survival 
in water and soil habitats. Based on such research, Grimont and Grimont (2006) has concluded that Serratia sp. with pigmentation abilities are existed in non-polluted rather than from polluted water.

Tolerance of Serratia marcescens HI6 to different extreme temperature, $\mathrm{pH}$ and media was assessed. Serratia marcescens HI6 was able to grow on temperature between $5-35^{\circ} \mathrm{C}\left(25^{\circ} \mathrm{C}\right.$ optimum growth temp), $\mathrm{pH}$ between 5-11 (7 optimum growth $\left.\mathrm{pH}\right)$ as well as on various media including ASW, LB, MSM, NB and PYM (LB optimum growth medium). Recently, Kaira et al. (2015) has reported similar findings for Serratia marcescens isolated from glacial site in Indian Himalayan Region (IHR). They observed psychrotolerant Serratia marcescens to show optimum growth at $25^{\circ} \mathrm{C}$. Many other researchers have also used various temperature $\left(5-37^{\circ} \mathrm{C}\right)$ for the growth of Serratia marcescens and they have found that it had the abilities to grow over a wide range of temperature (Bishop and Still, 1963; Selvakumar et al., 2008). In our knowledge, none of study has been carried out relating to tolerance of Serratia marcescens to extreme $\mathrm{pH}$ and various media.

In the present study, the fatty acids present in the cell membrane of Serratia marcescens HI6 were assessed using Fourier Transform Infrared (FTIR) spectroscopy. FTIR has the efficiency to recognize major parts of biological material (nucleic acids, proteins, lipids and carbohydrates) in any solution (Forfang et al., 2017). Basically, specific absorbance frequencies of FTIR are central to detect fatty acids (Forfang et al., 2017). In our study, the bands between 1710-1766 $\mathrm{cm}^{-1}$ were observed after analysis of extracted FAMEs by FTIR indicating the presence of $\mathrm{C}=\mathrm{O}$ that associated with fatty acids. According to Dean et al. (2010), presence of the band at $1740 \mathrm{~cm}^{-1}$ indicated existence of $\mathrm{C}=\mathrm{O}$ of ester groups, principally from FA. Moreover, Shurvell (2002) and Maquelin et al. (2002) has described the bands obtained from lipids after Fourier Transform Infrared spectroscopy analysis in detail. According to them, the lipid content present in any sample can easily detected by getting peaks associated to $\mathrm{C}-\mathrm{O}-\mathrm{C}$ stretching in esters $\left(1070-1250 \mathrm{~cm}^{-1}\right), \mathrm{CH}_{2}$ bending $\left(1460 \mathrm{~cm}^{-1}\right), \mathrm{C}=\mathrm{O}$ stretching in esters $\left(1745 \mathrm{~cm}^{-1}\right), \mathrm{C}-\mathrm{H}$ stretching vibrations $\left(=\mathrm{C}-\mathrm{H}\right.$ stretch at $\left.3010 \mathrm{~cm}^{-1}\right)$. The FTIR has been used by several researcher to identify the lipids and fatty acids content in many microbes such as Chlamydomonas reinhardti, Scenedesmus subspicatus, Mucor plumbeus, Mucor hiemalis, Mucor circinelloides, Mortierella alpine (Dean et al., 2010; Shapaval et al., 2014; Forfang et al., 2017).

Furthermore, the fatty acids profile of cell membrane of the isolate Serratiamarcescens HI6 was properly studied using Gas chromatography/mass spectroscopy (GC/MS) in the current study. Findings of this analysis showed that C16:1 was present abundantly in cell membrane of Serratia marcescens HI6. None of such study has been carried out in past. Although Bergan et al. (1983) and Bishop and Still (1963) have analyzed the whole cell fatty acids of Serratia marcescens, whereas, current study is focused on cell membrane fatty acids of Serratia marcescens, so it is very challenging to exactly compare and discuss current study (cell membrane fatty acids analysis) with previous studies (whole cell fatty acids analysis) of Serratia marcescens because whole cell fatty acids could significantly differ in type and function from fatty acids present in cell membrane. As distribution of various types of fatty acids in cell membrane play significant role in bacterial adaptability in cold habitats, therefore, present research work specifically focused on it rather than to study whole cell fatty acids. However, current study has generally been discussed with other related bacterial strains of Serratia marcescens (Jantzen et al., 1974a, b, 1975). Our 
results has supported by research work of many other researchers that observed foremost amount of C16:0, C16:1 and C18:1 in some strains of Serratia marcescens (Kates et al., 1964; Kates and Hagen, 1964). Although the contribution of the two last-mentioned fatty acids may also be small from the same strain Kates and Hagen (1964) has reported that amount of C16:1 and C18:1 varied depending upon culture conditions of growth of Serratia marcescens. It has been observed by many researcher that gram negative bacterial species possessed higher quantities of C16:0, C16:1 and C18:1 than gram positive bacteria in their cell membranes (Jantzen et al., 1974a,b, 1975; Zhao et al., 2011). Moreover, Bergan et al. (1983) has observed that family Enterobacteriaceae had high amount of C16:0 than C16:1 in their cells and has also reported in few Acinetobacter strains (Jantzen et al., 1975).

Likewise, the branched fatty acids were witnessed predominately in cell membrane the isolate Serratia marcescens HI6. The branched iso and anteiso pattern was observed in both saturated fatty acids and monounsaturated fatty acids in the current results. The incorporation of iso and anteiso branches in the fatty acids chains of cell membrane, is perhaps a strategy to cope with devastating effects of low temperature by maintaining the fluidity of cell membrane (Bajerski et al., 2013, 2017). In few studies, it has been shown that anteiso branches pattern of fatty acids of cell membranes in psychrotolerant bacterial species (such as Chryseobacterium frigidum and Chryseobacterium haifense) reduced the melting temperature of the plasma membrane increasing motion capability and made it possible to freely move molecules across the cell membrane (Hantsis-Zacharov and Halpern, 2007; Kim et al., 2016).

\section{Conclusion}

In conclusion, the bacterium isolate HI6 was identified as Serratia marcescens after $16 \mathrm{~S}$ rRNA sequencing. The bacterium isolate Serratia marcescens HI6 showed a good potential to grow over a wide range of extreme physiological conditions. Results of FTIR and GC/MS has showed that the isolate HI6 had the ability to produce and accumulate various types of fatty acids in its cell membrane but predominantly $i-\mathrm{C} 16: 1$ and other branched chain fatty acids. This study is important because it gives a clear idea about Fatty acids distribution in the cell membrane of Serratia marcescens and their possible role in adaptation in glacial habitats. In addition, this study would be helpful to understand the maintenance of cell membrane fluidity in glacial environments by Serratia marcescens. Finally, the bacterium isolate Serratia marcescens-HI6 would be used as source of polyunsaturated fatty acids (e.g. linoleic acid) as alternative to the conventional plant sources of PUFA, thus would be helpful to prevent deforestation.

Conflict of interests. The authors declare that the research was conducted in the absence of any commercial or financial relationships that could be construed as a potential conflict of interests.

Author contributions. All authors have made an equal contributions to the research work and writing of this manuscript. 


\section{REFERENCES}

[1] Abd El Razak, A., Ward, A. C., Glassey, J. (2014): Screening of Marine Bacterial Producers of Polyunsaturated Fatty Acids and Optimisation of Production. - Microb Ecol 67: 454-464.

[2] Abdour, A. M. (2003): Purification and partial characterization of psychrotrophic Serratia marcescens lipase. - Journal of Dairy Science 86: 127-132.

[3] Annous, B. A., Becker, L. A., Bayles, D. O., Labeda, D. P., Wilkinson, B. J. (1997): Critical role of anteiso-C15:0 fatty acid in the growth of Listeria monocytogenes at low temperatures. - Applied Environmental Microbiology 63: 3887-3894.

[4] Bahar, A. A., Demirbag, Z. (2007): Isolation of pathogenic bacteria from Oberea linearis (Coleoptera: Cerambycidae). - Biology 62: 13-18.

[5] Bajerski, F., Wagner, D. (2013): Bacterial succession in Antarctic soils of two glacier forefields on Larsemann Hills, East Antarctica. - FEMS Microbiology Ecology 85: 128142.

[6] Bajerski, F., Ganzert, L., Mangelsdorf, K., Padur, L., Lipski, A., Wagner, D. (2013): Chryseobacterium frigidisoli sp. nov., a psychrotolerant species of the family Flavobacteriaceae isolated from sandy permafrost from a glacier forefield. - International Journal of Systematic and Evolutionary Microbiology 63: 2666-2671.

[7] Bajerski, F., Wagner, D., Mangelsdorf, K. (2017): Cell Membrane Fatty Acid Composition of Chryseobacterium frigidisoli PB4T, Isolated from Antarctic Glacier Forefield Soils, in Response to Changing Temperature and pH Conditions. - Frontiers in Microbiology 8: 677.

[8] Bakermans, C., Bergholz, P. W., Rodrigues, D. F., Vishnivetskaya, T. A., Ayaladel-Rio, H. L., Tiedje, J. M. (2012): Genomic and expression analyses of cold-adapted microorganisms. - In: Miller, R. V., Whyte, L. G. (eds.) Polar Microbiology. Life in a Deep Freeze, Washington, DC, ASM Press, p. 126-155.

[9] Bergan, T., Grimont, P. A. D., Grimont, F. (1983): Fatty Acids of Serratia Determined by Gas Chromatography. - Current Microbiology 8: 7-11.

[10] Bermingham, M. A., Deol, B. S., Still, J. L. (1971): The relationship between prodigiosin biosynthesis and cyclic depsipeptides in Serratia marcescens. - Journal of General Microbiology 67(3): 319-24.

[11] Beveridge, T. J. (2001): Use of the Gram stain in microbiology. - Biotechnic and Histochemistry 76: 111-118.

[12] Bishop, D. G., Still, J. L. (1963): Fatty acid metabolism in Serratia marcescens: IV. The effect of temperature on fatty acid composition. - Journal of Lipid Research 4: 87-90.

[13] Bizio, B. (1823): Lettera di Bartolomeo Bizio al chiarissimo canonico Angelo Bellani sopra il fenomeno della polenta porporina. Biblioteca Italiana o sia Giornale di Letteratura. - Scienze a Arti 30: 275-295.

[14] de Queiroz, B. P. V., de Melo, I. S. (2006): Antagonism of Serratia marcescens towards Phytophthora parasitica and its effects in promoting the growth of citrus. - Brazilian Journal of Microbiology 37: 448-450.

[15] Dean, A. P., Sigee, D. C., Estrada, B., Pittman, J. K. (2010): Using FTIR spectroscopy for rapid determination of lipid accumulation in response to nitrogen limitation in freshwater microalgae. - Bioresource Technology 101: 4499-507.

[16] Dhar-Purkayastha, G., Mangar, P., Saha, A., Saha, D. (2018): Evaluation of the biocontrol efficacy of a Serratia marcescens strain indigenous to tea rhizosphere for the management of root rot disease in tea. - PLoS ONE 13(2): e0191761. doi.org/10.1371/journal.pone.0191761.

[17] Flyg, C., Xanthopoulos, K. G. (1983): Insect pathogenic properties of Serratia marcescens, passive and active resistance to insect immunity studied with protease deficient and phage-resistant mutants. - Journal of General Microbiology 129: 453-464. 


$$
-11922 \text { - }
$$

[18] Forfang, K., Zimmermann, B., Kosa, G., Kohler, A., Shapaval, V. (2017): FTIR Spectroscopy for Evaluation and Monitoring of Lipid Extraction Efficiency for Oleaginous Fungi. - PLOS ONE 12.

[19] Ganzert, L., Lipski, A., Hubberten, H. W., Wagner, D. (2011): The impact of different soil parameters on the community structure of dominant bacteria from nine different soils located on Livingston Island, South Shetland Archipelago, Antarctica. - FEMS Microbiology Ecology 76: 476-491.

[20] Gaughran, E. R. L. (1969): From superstition to science: The history of a bacterium. Transactions of the New York Academy of Sciences 31: 3-24.

[21] Gavini, F., Ferragut, C., Izard, D., Trinel, P. A., Leclerc, H., Lefebvre, B., Mossel, D. A. A. (1979): Serratia fonticola, a new species from water. - International journal of systematic bacteriology 29: 92-101.

[22] Ghaith, D. M., Zafer, M. M., Ismail, D. K., Al-Agamy, M. H., Bohol, M., Al-Qahtani, A., Mostafa, I. Y. (2018): First reported nosocomial outbreak of Serratia marcescens harboring blaIMP-4 and blaVIM-2 in a neonatal intensive care unit in Cairo, Egypt. Infection and drug resistance 11: 2211-2217.

[23] Grimont, P. A. D., Grimont, F. (1984): Genus VIII. Serratia. - In: Krieg, N. R., Holt, J. G. (eds.) Bergey's Manual of systematic bacteriology. Williams and Wilkins, Baltimore, p. $477-484$.

[24] Grimont, F., Grimont, P. A. D. (2006): The Genus Serratia. - Prokaryotes 6: 219-244.

[25] Groscop, J. A., Brent, M. M. (1964): The effects of selected strains of pigmented microorganisms on small free living amoebae. - Canadian Journal Microbiology 10: 579584.

[26] Hantsis-Zacharov, E., Halpern, M. (2007): Chryseobacterium haifense sp. nov., a psychrotolerant bacterium isolated from raw milk. - International Journal of Systematic and Evolutionary Microbiology 57: 2344-2348.

[27] Harrison, F. C. (1924): The "miraculous" microorganism. - Transactions of the Royal Society of Canada 18: 1-17.

[28] Janota-Bassalik, L. (1963): Psychrophiles in low-moor peat. - Acta Microbiologica Polonica 12: 25-40.

[29] Jantzen, E., Bergan, T., Bovre, K. (1974a): Gas chromatography of bacteria whole cell methanolysates. VI. Fatty acid composition of strains within Micrococcaeeae. - Acta Pathologicae et Microbiologicae Scandinavicae 82(B): 785-798.

[30] Jantzen, E., Bryn, K., Bergan, T., Bovre, K. (1974b): Gas chromatography of bacterial whole cell methanolysates. V. Fatty acid composition of Neisseriae and Moraxellae. Acta Pathologicae et Microbiologicae Scandinavicae 82(B): 767-779.

[31] Jantzen, E., Bryn, K., Bergan, T., Bovre, K. (1975): Gas chromatography of bacterial whole cell methanolysates. VII. Fatty acid composition of Aeinetobacter in relation to the taxonomy of Neisseriaceae. - Acta Pathologicae et Microbiologicae Scandinavicae 83(B): 569-580.

[32] Kaira, G. S., Dhakar, K., Pandey, A. (2015): A psychrotolerant strain of Serratia marcescens (MTCC 4822) produces laccase at wide temperature and $\mathrm{pH}$ range. - AMB Express 5.

[33] Karkey, A., Joshi, N., Chalise, S., Joshi, S., Shrestha, S., Nguyen, T. N. T., Dongol, S., Basnyat, B., Baker, S., Boinett, C. J. (2018): Outbreaks of Serratia marcescens and Serratia rubidaea bacteremia in a central Kathmandu hospital following the 2015 earthquakes. - Transactions of the Royal Society of Tropical Medicine and Hygiene 112(10): 467-472.

[34] Kates, M., Hagen, P. O. (1964): Influence of temperature on fatty acid composition of psychrophilic and mesophilic Serratia species. - Canadian Journal Biochemistry 42: 481488.

[35] Kates, M., Adams, G. A., Martin, S. M. (1964): Lipids of Serratia marcescens. Canadian Journal Biochemistry 42: 461-479. 


$$
-11923 \text { - }
$$

[36] Kim, T., Kim, M., Kang, O., Jiang, F., Chang, X., Liu, P., Zhang, Y., Da, X., Zheng, C., Fang, C., Peng, F. (2016): Chryseobacterium frigidum sp. nov., isolated from high-Arctic tundra soil, and emended descriptions of Chryseobacterium bernardetii and Chryseobacterium taklimakanense. - International Journal of Systematic and Evolutionary Microbiology 66: 609-615.

[37] Kloepper, J. W., Tuzun, S., Liu, L., Wei, G. (1993): Plant growth-promoting rhizobacteria as inducers of systemic disease resistance. - In: Lumsden, R. D., Waughn, J. (eds.) Pest Management: Biologically Based Technologies. DC: American Chemical Society Books, Washington, p. 156-165.

[38] Mahlen, S. D. (2011): Serratia infections: from military experiments to current practice. Clinical Microbiology Reviews 24: 755-791.

[39] Maquelin, K., Choo-Smith, L. P., Kirschner, C., Ngo-Thi, N. A., Naumann, D., Puppels, G. J. (2002): Vibrational Spectroscopic Studies of Microorganisms. - In: Chalmers, J. M., Griffiths, P. R. (eds.) Handbook of Vibrational Spectroscopy. John Wiley and Sons, Chichester, United Kingdom.

[40] Martinec, T., Kocur, M. (1961a): The taxonomic status of Serratia marcescens Bizio. International Bulletin of Bacteriological Nomenclature and Taxonomy 11: 7-12.

[41] Montagnani, C., Cocchi, P., Lega, L., Campana, S., Biermann, K. P., Braggion, C., Pecile, P., Chiappini, E., de Martino, M., Galli, L. (2015): Serratia marcescens outbreak in a neonatal intensive care unit: crucial role of implementing hand hygiene among external consultants. - BMC Infectious Diseases 15:11. doi.org/10.1186/s12879-0140734-6.

[42] Pares, Y. (1964): Action de Serratia marcescens dans le cycle biologique des métaux. Annales de l'Institut Pasteur 107: 136-141.

[43] Parsons, J. B., Rock, C. O. (2013): Bacterial lipids: Metabolism and membrane homeostasis. - Progress in Lipid Research 52: 249-276.

[44] Raymann, K., Shaffer, Z., Moran, N. A. (2017): Antibiotic exposure perturbs the gut microbiota and elevates mortality in honeybees. - PLoS Biol 15:e2001861. doi:10.1371/journal.pbio.2001861.

[45] Reid, J. D., Stoufer, S. D., Ogrydziak, D. M. (1982): Efficient transformation of Serratia marcescens with pBR322 plasmid DNA. - Gene 17: 107-112.

[46] Sandner-Miranda, L., Vinuesa, P., Cravioto, A., Morales-Espinosa, R. (2018): The Genomic Basis of Intrinsic and Acquired Antibiotic Resistance in the Genus Serratia. Frontiers in Microbiology 9: 828. doi:10.3389/fmicb.2018.00828.

[47] Selvakumar, G., Mohan, M., Kundu, S., Gupta, A. D., Joshi, P., Nazim, S., Gupta, H. S. (2008): Cold tolerance and plant growth promotion potential of Serratia marcescens strain SRM (MTCC 8708) isolated from flowers of summer squash (Cucurbita pepo). Letters of Applied Microbiology 46: 171-175.

[48] Shapaval, V., Afseth, N. K., Vogt, G., Kohler, A. (2014): Fourier transform infrared spectroscopy for the prediction of fatty acid profiles in Mucor fungi grown in media with different carbon sources. - Microbial Cell Factories 13: 86.

[49] Shurvell, H. F. (2002): Spectra-Structure Correlations in the Mid- and Far-Infrared. - In: Chalmers, J. M., Griffiths, P. R. (eds.) Handbook of Vibrational Spectroscopy. John Wiley \& Sons, Ltd, Chichester, United Kingdom.

[50] Sleigh, J. D. (1983): Antibiotic resistance in Serratia marcescens. - BMJ 287: 16511653.

[51] Suutari, M., Laakso, S. (1994): Microbial fatty acids and thermal adaptation. - Critical Reviews in Microbiology 20: 285-328.

[52] Szewzyk, U., Szewzyk, R., Stenström, T. A. (1993): Growth and survival of Serratia marcescens under aerobic and anaerobic conditions in the presence of materials from blood bags. - Journal of Clinical Microbiology 31: 1826-1830. 
[53] Tamura, K., Nei, M. (1993): Estimation of the number of nucleotide substitutions in the control region of mitochondrial DNA in humans and Chimpanzees. - Molecular Biology and Evolution 10: 512-526.

[54] Thompson, J. D., Higgins, D. G., Gibson, T. J. (1994): CLUSTAL W: Improving the sensitivity of progressive multiple sequence alignment through sequence weighting, position-specific gap penalties and weight matrix choice. - Nucleic Acids Research 22: 4673-4680.

[55] Tripura, C., Sashidhar, B., Podile, A. R. (2007): Ethyl methanesulphonate mutagenesis enhanced mineral phosphate solubilization by groundnut-associated Serratia marcescens GPS-5. - Current Microbiology 54: 79-84.

[56] Wheat, R. P., Zuckerman, A., Rank, L. A. (1951): Infection due to Chromobacteria: report of eleven cases. - Archives of Internal Medicine 88: 461-466.

[57] Williams, R. P., Qadri, S. M. H. (1980): The pigment of Serratia. - In: von Graevenitz, A., Rubin, S. J. (eds.) The genus Serratia. CRC Press, Boca Raton, p. 31-79.

[58] Yeung, H., Chavarria, B., Shahsavari, D. (2018): A Complicated Case of Serratia marcescens Infective Endocarditis in the Era of the Current Opioid Epidemic. - Case Reports in Infectious Diseases. doi.org/10.1155/2018/5903589.

[59] Zhang, Y. M., Rock, C. O. (2008): Membrane lipid homeostasis in bacteria. - Nature Reviews Microbiology 6: 222-33.

[60] Zhao, Q., Bai, Y., Zhang, G., Zhu, S., Sheng, H., Sun, Y. (2011): Chryseobacterium xinjiangense sp. nov., isolated from alpine permafrost. - International Journal of Systematic and Evolutionary Microbiology 61: 1397-1401.

[61] Zhou, J. Z., Bruns, M. A., Tiedje, J. M. (1996): DNA recovery from soils of diverse composition. - Applied Environmental Microbiology 62: 316-322. 